\title{
PENGARUH PENAMBAHAN GIPSUM TERHADAP KUAT TEKAN BEBAS TANAH LEMPUNG EKSPANSIF AKIBAT SIKLUS BASAH - KERING
}

\author{
Bunyamin Andreatama ${ }^{1}$ dan Aniek Prihatiningsih ${ }^{2}$ \\ ${ }^{1}$ Program Studi Sarjana Teknik Sipil, Universitas Tarumanagara, Jl. Letjen S. Parman No.1 Jakarta \\ Email: bunyaminandreatama@gmail.com \\ ${ }^{2}$ Program Studi Sarjana Teknik Sipil, Universitas Tarumanagara, Jl. Letjen S. Parman No.1 Jakarta \\ Email: aniekp@ft.untar.ac.id
}

\begin{abstract}
ABSTRAK
Perubahan kedalaman muka air tanah merupakan masalah utama yang membuat tanah ekspansif memiliki sifat merusak. Kedalaman tanah dimana sering terjadi perubahan kedalaman muka air tanah inilah yang disebut active zone karena tanah ekspansif hanya aktif pada kedalaman tersebut. Salah satu cara yang sudah banyak diterapkan di lapangan untuk mengatasi tanah ekspansif ini adalah stabilisasi tanah menggunakan kapur. Namun saat ini dilakukan berbagai penelitian untuk mencari material lain yang lebih mudah diperoleh. Gipsum memiliki unsur kalsium yang juga terdapat di dalam kapur. Oleh karena itu gipsum dipertimbangkan sebagai pengganti kapur. Dalam penelitian sebelumnya diketahui bahwa gipsum dapat meningkatkan kuat geser tanah. Pada penelitian ini tanah yang dicampur gipsum diuji kuat tekan bebasnya terhadap siklus basah-kering sebagai gambaran active zone. Pengambilan sampel tanah dilakukan di Jl. Science Timur 2 Jayamukti, Cikarang Pusat, Bekasi, Jawa Barat. Penambahan gipsum yang digunakan adalah 0\%, 4\% dan 8\% dengan waktu pemeraman sampel 0 hari, 3 hari dan 7 hari. Pemeraman sampel dilakukan dengan menaruh sampel pada desiccator selama waktu peemraman. Jumlah siklus basah-kering yang dilakukan adalah tanpa siklus, 1 siklus dan 2 siklus dengan pengertian 1 siklus adalah sampel direndam hingga keadaan jenuh, lalu dikeringkan hingga kembali ke kadar air optimumnya. Dari penelitian ini diperoleh hasil sampel yang tidak melalui siklus basah-kering kuat tekan bebasnya meningkat pada pencampuran gipsum $8 \%$ namun menurun untuk kadar gipsum 4\%. Tetapi setelah melalui siklus basah-kering tidak diperoleh suatu kecenderungan umum pada penambahan kadar gipsum terhadap kuat tekan bebas tanah.
\end{abstract}

Kata kunci: Tanah Ekspansif, Siklus Basah-Kering, Stabilisasi Tanah, Kuat Tekan Bebas, Gipsum

\section{PENDAHULUAN}

\section{Latar Belakang}

Kemajuan dalam bidang konstruksi membuat pembangunan berbagai infrastruktur dan bangunan lainnya berkembang dengan pesat. Tanah sebagai dasar berdirinya suatu konstruksi bangunan menjadi hal yang sangat penting untuk diperhatikan. Salah satu masalah yang seringkali ditemukan pada tanah di Indonesia adalah tanah lempung yang bersifat ekspansif. Sejak disadari efek kerusakan yang disebabkan oleh tanah ekspansif, sejumlah kerugian mulai dirasakan oleh masyarakat. Kejadian ini menjadi salah satu persoalan besar yang harus segera diatasi karena sifat kerusakan yang ditimbulkan pada umumnya terjadi dalam jangka waktu yang relatif lama dan terjadi secara terus-menerus. Sifat tanah ekspansif yang berbahaya adalah kemampuan mengembangnya yang cukup besar pada keadaan basah dan sifat menyusut yang terjadi pada keadaan kering sehingga dapat menyebabkan terjadinya deformasi yang sulit dipikul oleh struktur bangunan di atasnya. Perilaku tanah ekspansif yang merusak terjadi secara signifikan pada lapisan yang sering mengalami perubahan ketinggian muka air tanah atau yang sering disebut sebagai active zone. Perubahan kadar air dalam tanah inilah yang dapat membuat tanah ekspansif mengembang pada keadaan basah dan menyusut pada keadaan kering.

Saat ini sebenarnya sudah ada beberapa cara yang dapat dilakukan untuk mencegah atau mengurangi pengaruh kerusakan yang dapat ditimbullan oleh tanah ekspansif, seperti mengganti tanah ekspansif dengan tanah yang lebih baik, perkuatan struktur bawah, pemasangan drainase yang baik atau stabilisasi secara kimia. Salah satu metode perbaikan tanah ekspansif yang cukup dikenal adalah stabilisasi menggunakan kapur. Namun saat ini sudah dilakukan berbagai penelitian menggunakan bahan lain selain kapur untuk stabilisasi tanah ekspansif, salah satunya menggunakan gipsum. Bahan ini dapat dipertimbangkan sebagai salah satu pengganti kapur karena sama-sama mengandung kalsium (Kapur $\mathrm{CaO}$ atau $\mathrm{Ca}(\mathrm{OH})_{2}$ dan Gipsum $\mathrm{CaSO}_{4} \cdot 2 \mathrm{H}_{2} \mathrm{O}$ ). Pada penelitian sebelumnya yang dilakukan oleh Wibawa (2015), didapat hasil bahwa penambahan gipsum pada tanah lempung dapat meningkatkan 
kekuatan geser tanah melalui pengujian geser langsung (direct shear). Namun penelitian tersebut belum menguji kemampuan gipsum sebagai stabilisasi tanah dalam kondisi perubahan kadar air yang terjadi secara berulang. Oleh karena itu pada penelitian ini akan diuji pengaruh penambahan gipsum terhadap kuat tekan bebas tanah lempung ekspansif akibat siklus basah-kering.

Pengambilan sampel tanah dilakukan pada lokasi yang beralamat di Jl. Science Timur 2 Jayamukti, Cikarang Pusat, Bekasi, Jawa Barat 17530, Indonesia, tepatnya di seberang PT. Ethica Industri Farmasi dengan koordinat titik $6^{\circ} 19^{\prime} 28.1^{\prime \prime S} 107^{\circ} 10^{\prime} 46.3 " \mathrm{E}$.

\section{Rumusan Masalah}

1. Bagaimana pengaruh persentase kadar campuran gipsum pada tanah lempung ekspansif terhadap nilai kuat tekan bebas tanah?

2. Bagaimana nilai kuat tekan bebas tanah lempung ekspansif yang telah dicampur dengan gipsum dan yang tidak dicampur setelah melalui siklus basah-kering?

3. Bagaimana pengaruh durasi pemeraman sampel uji tanah lempung ekspansif yang dicampur dengan gipsum terhadap nilai kuat tekan bebas tanah sebelum dan sesudah melalui siklus basah-kering?

4. Bagaimana pengaruh jumlah siklus basah-kering yang dilakukan pada sampel uji terhadap nilai kuat tekan bebas tanah?

\section{Tujuan Penelitian}

1. Mengamati pengaruh persentasi kadar campuran gipsum pada tanah lempung ekspansif terhadap nilai kuat tekan.

2. Mengetahui nilai kuat tekan bebas tanah lempung ekspansif yang telah dicampur dengan gipsum dan yang tidak dicampur setelah melalui siklus basah-kering.

3. Mengetahui pengaruh durasi pemeraman sampel uji tanah lempung ekspansif yang dicampur dengan gipsum terhadap nilai kuat tekan bebas tanah sebelum dan sesudah melalui siklus basah-kering.

4. Mengamati pengaruh jumlah siklus basah-kering yang dilakukan pada sampel uji terhadap nilai kuat tekan bebas tanah.

\section{TINJAUAN PUSTAKA}

\section{Klasifikasi dan Sifat-sifat Tanah Lempung Eksapansif}

Klasifikasi tanah berbutir kasar umumnya hanya bergantung pada analisa saringan dan distribusi ukuran partikelnya. Namun untuk klasifikasi tanah berbutir halus juga dibutuhkan indeks plastisitas seperti yang ditunjukan grafik pada Gambar 1 .

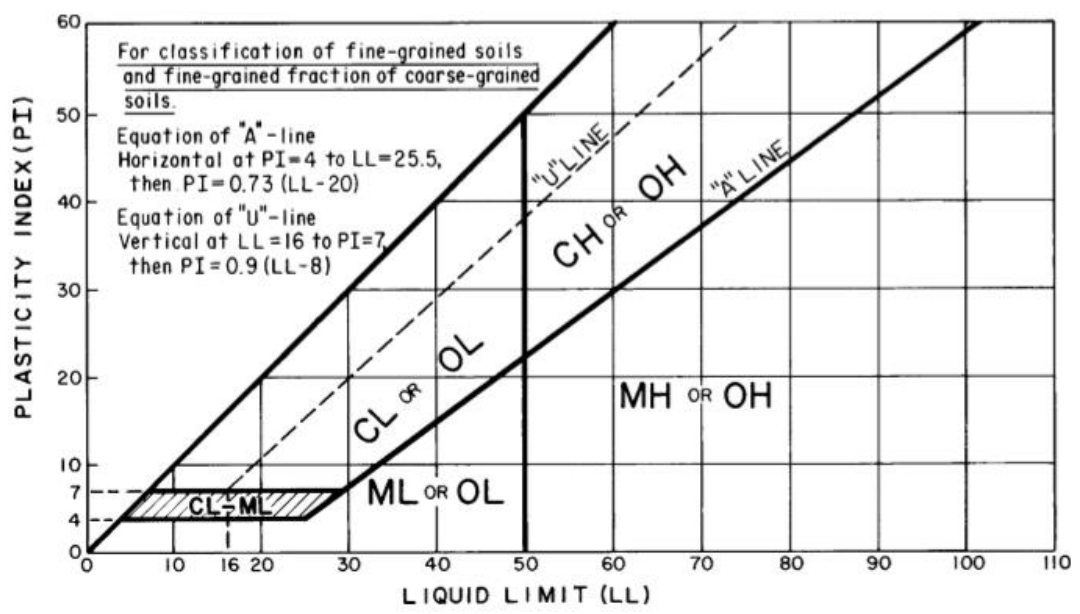

Gambar 1. Klasifikasi Tanah Berbutir Halus dengan Liquid Limit dan Plasticity Index (ASTM D2487-10)

Untuk mengetahui sifat-sifat tanah, terutama tanah berbutir halus, dibutuhkan beberapa pengujian laboratorium. Beberapa pengujian laboratorium yang harus dilakukan antara lain Index Properties (Kadar air, berat jenis dan angka pori), Specific Gravity Test, Atterberg Limits, Sieve Analysis, Hydrometer Analysis. 
Dengan melalui pengujian-pengujian tersebut maka akan didapat sifat-sifat dasar tanah yang penting untuk diperhatikan. Salah satu masalah yang sering terjadi dalam dunia teknik sipil adalah tanah lempung yang bersifat ekspansif (expansive soil). Tanah ini memiliki karakteristik yang cukup membahayakan karena dapat mengembang pada kondisi basah dan menyusut pada kondisi kering secara drastis. Biasanya sifat tanah ekspansif dapat diketahui melalui nilai plasticity index yang didapat dari uji Atterberg Limits seperti dapat dilihat pada Tabel 1.

Tabel 1. Relation of soil index properties to expansion potential of high-plasticity clay soils. (USBR 1998:46)

\begin{tabular}{|c|c|c|c|c|}
\hline Colloid Content & Plasticity Index & Shrinkage Limit & $\begin{array}{c}\text { Probable } \\
\text { Expansion (\% } \\
\text { Total Vol. } \\
\text { Change }\end{array}$ & $\begin{array}{c}\text { Degree of } \\
\text { Expansion }\end{array}$ \\
\hline$>28$ & $>35$ & $<11$ & $>30$ & Very High \\
\hline $20-31$ & $25-41$ & $7-12$ & $20-30$ & High \\
\hline $13-23$ & $15-28$ & $10-16$ & $10-20$ & Medium \\
\hline$<15$ & $<18$ & $>15$ & $<10$ & Low \\
\hline
\end{tabular}

Tiga buah mineral utama yaitu montmorillonite, illite dan kaolinite ada dalam kandungan tanah lempung. Tanah ekspansif sangat dipengaruhi oleh mineral montmorillonite, mineral ini terjadi sebagai hasil pelapukan mineralmineral ferromagnesian, calcic feldspar dan mineral vulkanik (Makarim et al, 2017).

Menurut Wesley (2010:5), Montmorillonite memiliki sifat aktivitas tinggi; illite rnemiliki sifat akivitas sedang, dan kaolinite memiliki sifat aktivitas rendah. Lempung yang mengandung montmorillonite memiliki sifat teknik yang buruk, khususnya sering menyebabkan kerusakan pada fondasi gedung akibat pengembangan dan penyusutan.

Menurut Skempton (1953) hubungan antara aktivitas tanah dan indeks plastisitas dapat dinyatakan dengan rumus:

$$
\text { Aktivitas }(A c)=\frac{P I}{c-10}
$$

Keterangan:

PI

c : persentase lempung lolos saringan $0.002 \mathrm{~mm}$

$\mathrm{n} \quad: 5$ atau 10 (n untuk tanah asli $=5$, sedangkan $\mathrm{n}$ remolded $=10$ )

Ac>1.25 : Tanah bersifat aktif dan ekspansif

$0.75>$ Ac $>1.25:$ Tanah digolongkan normal

Ac $<0.75 \quad:$ Tanah digolongkan tidak aktif

\section{Stabilisasi Tanah dengan Kapur}

Stabilisasi tanah secara umum dapat dilakukan secara mekanis maupun kimiawi. Beberapa metode umum yang sering digunakan untuk stabilisasi tanah secara kimiawi adalah stabilisasi menggunakan semen atau menggunakan kapur. Semen biasanya digunakan untuk stabilisasi pada tanah yang berbutir kasar. Sebaliknya kapur lebih cocok untuk diaplikasikan pada tanah yang berbutir halus dibandingkan dengan tanah berbutir kasar. Kapur yang biasa digunakan untuk stabilisasi tanah adalah kalsium hidroksida $\left(\mathrm{Ca}(\mathrm{OH})_{2}\right)$ atau kalsium oksida $(\mathrm{CaO})$.

\section{Kuat Tekan Bebas}

Kuat tekan bebas atau unconfined compressive strength $\left(\mathrm{q}_{\mathrm{u}}\right)$ adalah tegangan tekan dimana spesimen silinder tanah yang tidak dibatasi akan gagal dalam uji tekan sederhana; dalam metode uji ini, kuat tekan bebas diambil saat beban maksimum dicapai per satuan luas atau beban per satuan luas pada regangan aksial 15\%, dimana harus dijamin terlebih dahulu sebelum pelaksanaan pengujian. (ASTM D2166/D2166M-13). Selain bisa mendapatkan kuat tekan bebas tanah, dari pengujian ini juga bisa didapatkan kuat geser tanah atau shear strength $\left(\mathrm{S}_{\mathrm{u}}\right)$ yang dihitung sebesar $1 / 2$ dari unconfined compressive strength $\left(\mathrm{q}_{\mathrm{u}}\right)$.

\section{Gipsum}

Gipsum memiliki kandungan yang hampir mirip dengan kapur karena sama-sama mengandung kalsium. Namun gipsum merupakan garam kalsium karena susunan kimianya adalah kalsium sulfat hidrat $\left(\mathrm{CaSO}_{4} \cdot 2\left(\mathrm{H}_{2} \mathrm{O}\right)\right)$. 
Material ini dapat digunakan sebagai alternatif pengganti kapur karena mudah didapat. Dalam penelitian sebelumnya yang dilakukan Wibawa (2015), didapatkan hasil bahwa penambahan gipsum dapat meningkatkan nilai kuat geser tanah pada tanah lempung. Penelitian ini dilakukan dengan pengujian geser langsung atau direct shear test. Dari penelitiannya disimpulkan kenaikan nilai kuat geser terbesar adalah 116,34\% dibanding dengan tanah aslinya. Kenaikan nilai maksimum kuat geser tanah ini juga terjadi pada waktu pemeraman 14 hari.

Namun menurut Ingles dan Metcalf (1972), ada dua kerugian yang dapat ditimbulkan, yaitu menimbulkan efek yang berlawanan pada pemadatan atau kompaksi, dan cenderung meningkatkan permeabilitas tanah sehingga lebih mudah larut atau tercuci aliran air.

\section{Siklus Basah Kering}

Sebagaimana telah diketahui bahwa efek kerusakan tanah lempung ekspansif sangat dipengaruhi oleh perubahan kadar air dalam tanah, sehingga apabila kadar air atau ketinggian muka air tanah pada kedalaman tertentu itu stabil, maka tanah ekspansif tidak memberikan dampak yang berarti. Namun fluktuasi atau perubahan muka air tanah yang sering terjadi pada kedalaman tanah tertentu, dapat membuat tanah ekspansif memberikan dampak merusak untuk struktur bangunan yang ada di atasnya. Kedalaman tanah dimana fluktuasi muka air tanah itu sering terjadi disebut sebagai zona aktif atau active zone.

\section{METODOLOGI PENELITIAN}

\section{Pengambilan Sampel Tanah}

Pengambilan sampel tanah dilakukan pada tanah datar dengan kedalaman 0-0.5 meter dari permukaan tanah aslinya dan tanah yang diambil merupakan sampel tanah terganggu (disturbed). Selain itu juga diambil sampel tanah menggunakan Ring Index Properties dengan cara ditekan pada tanah tersebut lalu sampel dibungkus menggunakan plastic wrap sehingga sedapat mungkin didapat kondisi tanah mendekati keadaan asli untuk pengujian kadar air dan angka pori.

\section{Pengujian Awal Sifat-sifat Tanah}

Sampel tanah yang sudah diambil selanjutnya dibawa ke Laboratorium Mekanika Tanah Universitas Tarumanagara untuk dilakukan pengujian awal sifat-sifat tanah. Pengujian ini dilakukan untuk mengetahui jenis dan sifat-sifat tanah dari sampel yang sudah diambil. Pengujian tersebut antara lain meliputi Index Properties (Kadar air, berat jenis dan angka pori), Specific Gravity Test, Atterberg Limits, Sieve Analysis, Hydrometer Analysis, dan Uji X-Ray Diffraction

Untuk pengujian X-Ray Diffraction dilakukan oleh Laboratorium PT. SUCOFINDO (Persero). Selain pengujian sifat-sifat tanah, dilakukan juga pengujian compaction atau kompaksi untuk menentukan kadar air optimum karena untuk pembuatan sampel pengujian kuat tekan bebas, campuran tanah dan serbuk gipsum akan dicampur dengan kadar air optimum. Seluruh pengujian yang dilakukan mengacu pada prosedur standar dari ASTM (American Society for Testing and Materials) dan AASHTO (American Association of State Highway and Transportation Officials).

\section{Uji Hubungan Plasticity Index dengan Temperatur Suhu Tinjauan}

Karena penelitian ini akan berhubungan dengan siklus basah-kering, maka diperlukan peninjauan suhu yang akan digunakan untuk metode pengeringan sampel. Pengujian ini dilakukan dengan melihat pengaruh temperatur pengeringan sampel dengan indeks plastisitas sampel yang dikeringkan pada suhu-suhu tertentu. Pilihan metode pengeringan yang akan digunakan antara lain: kondisi kering udara, kering oven $50^{\circ} \mathrm{C}, 60^{\circ} \mathrm{C}$ dan $70^{\circ} \mathrm{C}$

Nilai-nilai indeks plastisitas dari temperatur-temperatur tersebut akan dibandingkan dengan kondisi kering udara karena mendekati proses pengeringan asli. Apabila terjadi penyimpangan nilai indeks plastisitas yang cukup besar, maka akan digunakan temperatur yang nilai indeks plastisitasnya mendekati kondisi kering udara.

\section{Persiapan Benda Uji (Tanah + Gipsum)}

Pencampuran tanah dengan gipsum dilakukan dalam keadaan kering, lalu dicampur air dengan kadar air optimum. Gipsum yang digunakan adalah gipsum compound berbentuk bubuk merek Aplus. Tanah yang dalam keadaan kering tersebut harus lolos pada saringan No. 4. Persentase kadar gipsum yang akan digunakan antara lain $0 \%$ (tanpa gipsum), $4 \%$ dan $8 \%$. Persentase tersebut merupakan perbandingan berat gipsum dengan berat kering tanah. 


\section{Pengujian Kuat Tekan Bebas (UCS)}

Untuk membuat sampel uji kuat tekan bebas, dilakukan dengan pemadatan standard proctor dengan kadar air optimum. Selanjutnya sampel dicetak pada mold UCS dengan ukuran standar sesuai ASTM. Sampel tanah yang dicampur dengan gipsum juga akan divariasikan dengan waktu pemeramannya, yaitu selama 0 hari, 3 hari dan 7 hari, sehingga didapatkan 7 macam jenis sampel, sehingga didapatkan 7 macam jenis sampel dengan deskripsi sebagai berikut:

1. $\quad 0 \%$ - 0 Hari $\rightarrow$ Sampel tanpa campuran gipsum dan tanpa masa pemeraman

2. $4 \%$ - 0 Hari $\rightarrow$ Sampel dengan campuran gipsum $4 \%$ dan tanpa masa pemeraman

3. $4 \%-3$ Hari $\rightarrow$ Sampel dengan campuran gipsum $4 \%$ dan dengan masa pemeraman 3 hari

4. $\quad 4 \%-7$ Hari $\rightarrow$ Sampel dengan campuran gipsum $4 \%$ dan dengan masa pemeraman 7 hari

5. $\quad 8 \%-0$ Hari $\rightarrow$ Sampel dengan campuran gipsum $8 \%$ dan tanpa masa pemeraman

6. $\quad 8 \%-3$ Hari $\rightarrow$ Sampel dengan campuran gipsum $8 \%$ dan dengan masa pemeraman 3 hari

7. $8 \%-7$ Hari $\rightarrow$ Sampel dengan campuran gipsum $8 \%$ dan dengan masa pemeraman 7 hari

Ketujuh sampel tersebut masing-masing akan diuji melalui 0 siklus basah kering, 1 kali siklus basah kering dan 2 kali siklus basah kering sehingga totalnya didapatkan 21 jenis sampel. 21 jenis sampel tersebut akan dibuat sebanyak 3 buah benda uji sehingga total keseluruhan sampel yang akan dibuat adalah 63 sampel.

Siklus basah-kering untuk penelitian ini tidak memiliki standar metode pengujian yang spesifik untuk campuran gipsum maupun kapur. Namun standar metode pengujian yang paling mendekati adalah ASTM D559-03 (Standard Test Methods for Wetting and Drying Compacted Soil-Cement Mixture). Pengertian 1 siklus adalah sampel sudah mengalami perendaman hingga keadaan jenuh, lalu dikeringkan hingga kembali ke kadar air optimumnya. Untuk memastikan sampel sudah dalam keadaan jenuh air, maka sampel kembali direndam kemudian ditimbang lagi keesokan harinya. Apabila berat sampel tidak berubah, maka dapat diasumsikan sampel sudah jenuh air.

\section{ANALISIS HASIL DAN PEMBAHASAN}

\section{Uji Nilai Specific Gravity}

Pengujian nilai specific gravity dilakukan dengan mengacu pada standar AASHTO T 100. Dari pengujian tersebut diperoleh data seperti ditunjukan pada Tabel 2.

Tabel 2. Hasil Uji Nilai Specific Gravity

\begin{tabular}{|c|c|c|}
\hline Keterangan & Sampel 1 & Sampel 2 \\
\hline Gs $\left(\mathrm{Tx}=24^{\circ} \mathrm{C}\right)$ & 2.73 & 2.68 \\
\hline Gs $\left(20^{\circ} \mathrm{C}\right)$ & 2.72 & 2.68 \\
\hline Rata-rata Gs & \multicolumn{2}{|c|}{2.70} \\
\hline
\end{tabular}

\section{Uji Index Properties Tanah}

Pengujian Index Properties tanah dilakukan menggunakan sampel undisturbed sehingga parameter yang diperoleh dapat mendekati keadaan tanah aslinya. Berikut adalah hasil pengujian tersebut yang dapat dilihat pada Tabel 3.

Tabel 3. Hasil Uji Index Properties

\begin{tabular}{|c|c|c|c|c|}
\hline Ket. & \multicolumn{2}{|c|}{ Sampel 1} & \multicolumn{2}{|c|}{ Sampel 2} \\
\hline $\mathrm{w}(\%)$ & \multicolumn{2}{|c|}{$45 \%$} & \multicolumn{2}{|c|}{$40 \%$} \\
\hline Gs & \multicolumn{2}{|c|}{2.70} & \multicolumn{2}{|c|}{2.70} \\
\hline$\gamma$ wet & $1.76\left(\mathrm{gr} / \mathrm{cm}^{3}\right)$ & $17.23\left(\mathrm{kN} / \mathrm{m}^{3}\right)$ & $1.80\left(\mathrm{gr} / \mathrm{cm}^{3}\right)$ & $17.67\left(\mathrm{kN} / \mathrm{m}^{3}\right)$ \\
\hline$\gamma d r y$ & $1.21\left(\mathrm{gr} / \mathrm{cm}^{3}\right)$ & $11.8933\left(\mathrm{kN} / \mathrm{m}^{3}\right)$ & $1.29\left(\mathrm{gr} / \mathrm{cm}^{3}\right)$ & $12.63\left(\mathrm{kN} / \mathrm{m}^{3}\right)$ \\
\hline $\mathrm{S}(\%)$ & \multicolumn{2}{|c|}{$98.71 \%$} & \multicolumn{2}{|c|}{$98.22 \%$} \\
\hline $\mathrm{e}$ & \multicolumn{2}{|c|}{1.23} & \multicolumn{2}{|c|}{1.10} \\
\hline $\mathrm{n}$ & \multicolumn{2}{|c|}{0.55} & \multicolumn{2}{|c|}{0.52} \\
\hline$\gamma$ sat. & $1.76\left(\mathrm{gr} / \mathrm{cm}^{3}\right)$ & $17.30\left(\mathrm{kN} / \mathrm{m}^{3}\right)$ & $1.81\left(\mathrm{gr} / \mathrm{cm}^{3}\right)$ & $17.76\left(\mathrm{kN} / \mathrm{m}^{3}\right)$ \\
\hline
\end{tabular}




\section{Uji Atterberg Limits}

Pengujian Atterberg Limits ini dilakukan dengan mengacu pada standar ASTM D4318. Dari pengujian ini dapat diperoleh nilai batas cair / Liquid Limit (LL), batas plastis / Plastic Limit (PL), indeks plastisitas / Plasticity Index (PI), dan klasifikasi jenis tanah berbutir halus. Untuk hasil dari nilai Liquid Limit (LL), Plastic Limit (PL), dan Plasticity Index (PI) dapat dilihat pada Tabel 4.

Tabel 4. Nilai Liquid Limit (LL), Plastic Limit (PL), dan Plasticity Index (PI)

\begin{tabular}{|l|c|c|c|}
\cline { 2 - 4 } \multicolumn{1}{c|}{} & Sampel 1 & Sampel 2 & Rata-rata \\
\hline Liquid Limit (LL) (\%) & 85.74 & 85.07 & 85.40 \\
\hline Plastic Limit (PL) (\%) & 39.23 & 39.59 & 39.41 \\
\hline Plasticity Index (PI) (\%) & 46.50 & 45.47 & 45.99 \\
\hline
\end{tabular}

\section{Uji Grain Size (Sieve Analysis dan Hydrometer Analysis)}

Pengujian Grain Size Analysis dilakukan dengan mengacu pada standar pengujian ASTM D422, dimana pengujian ini dilakukan dalam 2 bagian, yaitu Sieve Analysis untuk butiran tanah yang tertahan pada saringan No. 200 dan Hydrometer Analysis untuk tanah yang lolos saringan No. 200. Grafik hasil dari pengujian Sieve Analysis dan Hydrometer Analysis dapat dilihat pada Gambar 3.

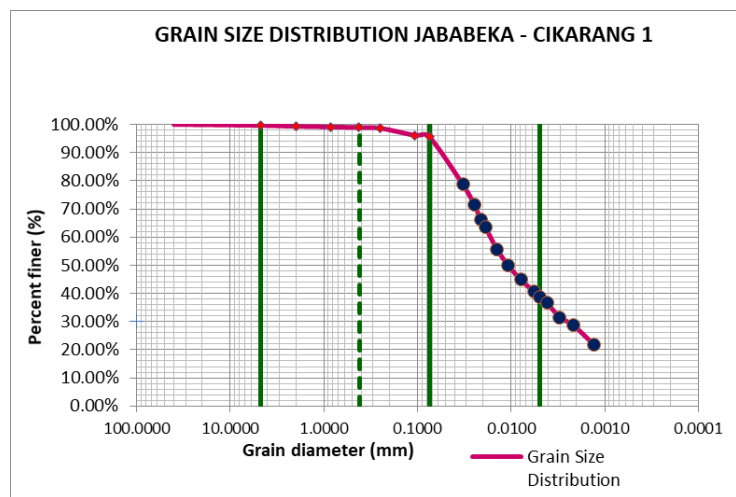

(a) Sampel 1

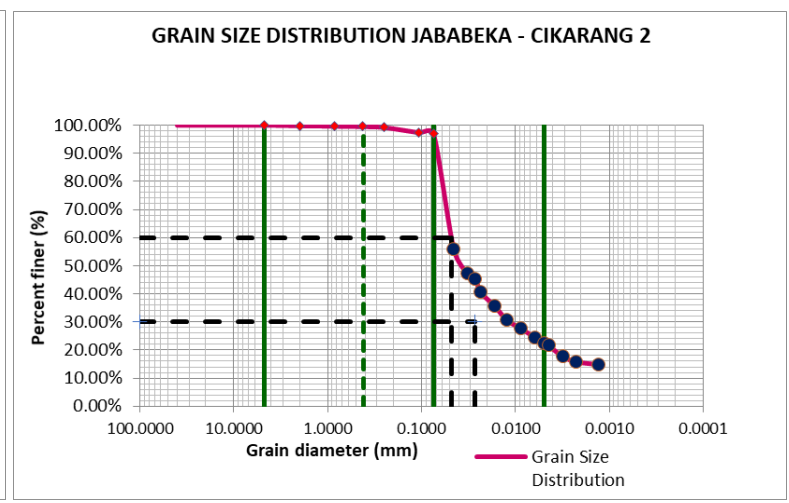

(b) Sampel 2

Gambar 3. Grafik Hasil Pengujian Sieve Analysis dan Hydrometer Analysis

Untuk persentase komposisi distribusi butiran tanah pada kedua sampel dapat dilihat pada Tabel 5

Tabel 5 Persentase Distribusi Komposisi Butiran Tanah

\begin{tabular}{|c|c|c|c|}
\hline Jenis Tanah & Sampel 1 & Sampel 2 & Rata-rata \\
\hline Persentase Gravel & $0.36 \%$ & $0.00 \%$ & $0.18 \%$ \\
\hline Persentase Sand & $4.36 \%$ & $2.98 \%$ & $3.67 \%$ \\
\hline Persentase Silt & $56.79 \%$ & $74.42 \%$ & $65.61 \%$ \\
\hline Persentase Clay & $38.85 \%$ & $22.60 \%$ & $30.73 \%$ \\
\hline
\end{tabular}

Dengan mengetahui persentase clay dan nilai Plasticity Index, maka dapat dihitung aktivitas sampel tanah yang terjadi menggunakan rumus 2.1 :

$$
\text { Aktivitas }(A c)=\frac{P I}{c-10}=\frac{45.99}{30.73-10}=2.22
$$

Karena nilai Ac $=2.22>1.25$, maka sampel tanah yang diambil termasuk aktif.

\section{Uji Mineral Tanah (X-Ray Diffraction)}

Pengujian mineral menggunakan X-Ray Diffraction pada sampel tanah yang diambil dilakukan oleh PT. SUCOFINDO (Persero) dengan meninjau beberapa mineral, yaitu Quartz, Montmorillonite, Kaolinite, Calcite dan Albite. Persentase komposisi masing-masing mineral dapat dilihat pada Tabel 6. 
Tabel 6. Komposisi Mineral Tanah Melalui Uji X-Ray Diffraction

\begin{tabular}{|c|l|c|}
\hline \multirow{4}{*}{ Sample Mark } & \multicolumn{1}{|c|}{ Mineral/s or Phase/s Identified } & $\begin{array}{c}\text { Estimation by } \\
\text { Normalized RIR Bulk } \\
\text { XRD } \\
\text { (\%) }\end{array}$ \\
\hline \multirow{5}{*}{ JABABEKA } & Quartz $\mathrm{SiO}_{2}$ & 80 \\
\cline { 2 - 3 } & $\begin{array}{l}\text { Montmorillonite } \\
(\mathrm{Ca}, \mathrm{Na})_{0.32} \mathrm{Al}_{2}\left(\mathrm{Si}_{2} . \mathrm{Al}_{4} \mathrm{O}_{10}(\mathrm{OH}) \mathrm{xH}_{2} \mathrm{O}\right.\end{array}$ \\
\cline { 2 - 3 } & Kaolinite $\mathrm{Al}_{2}\left(\mathrm{Si}_{2} \mathrm{O}_{5}\right)(\mathrm{OH})_{4}$ & 11 \\
\cline { 2 - 3 } & Calcite $\mathrm{CaCO}_{3}$ & 9 \\
\cline { 2 - 3 } & Albite $\mathrm{Na}_{0.685} \mathrm{Ca}_{0.347} \mathrm{Al}_{1.46} \mathrm{Si}_{2.54} \mathrm{O}_{8}$ & Trace \\
\cline { 2 - 3 } & \multicolumn{1}{|c|}{$\mathbf{X X X}$} & Trace \\
\hline
\end{tabular}

Dari hasil pengujian tersebut ditemukan adanya kandungan mineral Montmorillonite sebesar 11\%, sehingga sampel tanah yang diambil memiliki potensi sebagai tanah ekspansif.

\section{Uji Hubungan Plasticity Index (PI) dengan Temperatur Suhu Tinjauan}

Pada penelitian ini sampel akan diuji melalui siklus pembasahan dan pengeringan. Oleh karena itu untuk proses pengeringan dibutuhkan peninjauan terhadap temperatur pengeringan yang akan dilakukan. Suhu pengeringan tanah untuk pemanasan dengan oven dilakukan pada suhu $50^{\circ} \mathrm{C}, 60^{\circ} \mathrm{C}$ dan $70^{\circ} \mathrm{C}$. Pengujian juga dilakukan untuk tanah yang dikeringkan pada temperatur ruangan atau kering udara dengan suhu udara berkisar $27^{\circ} \mathrm{C}$. Grafik hasil dari pengujian hubungan Plasticity Index dengan temperatur suhu tinjauan dapat dilihat pada Gambar 4.

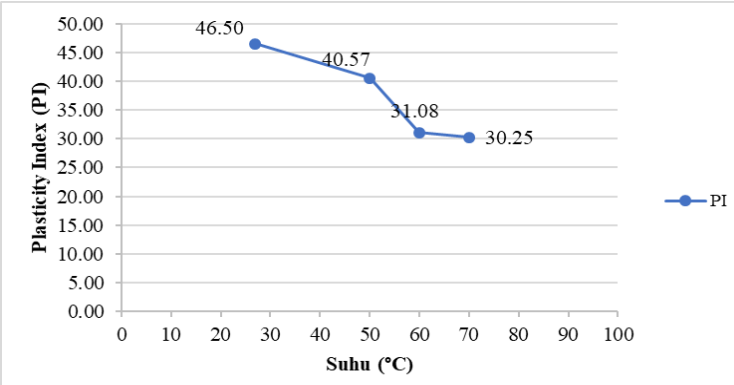

Gambar 4. Hubungan Plasticity Index dengan Temperatur Suhu Tinjauan

\section{Uji Pemadatan Standrad Proctor (Penentuan Kadar Air Optimum)}

Dalam pembuatan sampel untuk uji kuat tekan bebas, dibutuhkan kadar air optimum untuk dicampur dengan tanah kering yang lolos saringan No. 4 karena sampel yang dibuat merupakan sampel remolded / disturbed. Pengujian ini dilakukan dengan mengacu pada standar AASHTO T99-10 Metode B, dimana jumlah lapisan yang dipukul ada 3 lapis dan jumlah pukulan tiap lapisannya adalah 56 pukulan. Besar kadar air Optimum yang diperoleh dari hasil pengujian adalah $30.60 \%$ dan kepadatan kering tanah yang diperoleh adalah $13.43 \mathrm{kN} / \mathrm{m}^{3}$, seperti terlihat pada grafik dalam Gambar 5.

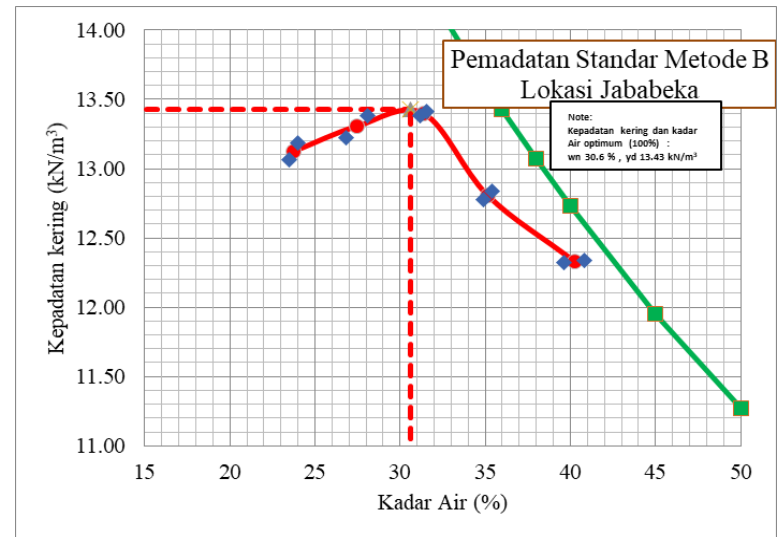

Gambar 5. Kadar Air Optimum dari Uji Pemadatan Standard Proctor 


\section{Pengaruh Kadar Gipsum Terhadap Tegangan Pada Tiap Kondisi Pemeraman dan Jumlah Siklus}

Rangkuman rata-rata nilai $\mathrm{q}_{\mathrm{u}}$ dari 2 sampel pada setiap kondisi dapat dilihat pada Tabel 7 dan grafik nilai $\mathrm{q}_{\mathrm{u}}$ terhadap jumlah siklus dapat dilihat pada Gambar 6

Tabel 7 Rangkuman Rata-rata Nilai qu untuk Analisis Kadar Gipsum

\begin{tabular}{|c|c|c|c|}
\hline \multirow{2}{*}{ Kondisi } & \multicolumn{3}{|c|}{$\mathrm{q}_{\mathrm{u}}\left(\mathrm{kN} / \mathrm{m}^{2}\right)$ untuk Kadar Gipsum $(\%)$} \\
\cline { 2 - 4 } & 0 & 4 & 8 \\
\hline 0H-0N & 284.27 & 192.19 & 268.88 \\
\hline $3 \mathrm{H}-0 \mathrm{~N}$ & 284.27 & 219.35 & 290.13 \\
\hline $7 \mathrm{H}-0 \mathrm{~N}$ & 284.27 & 265.32 & 438.17 \\
\hline 0H-1N & 160.75 & 148.85 & 163.90 \\
\hline 3H-1N & 160.75 & 188.19 & 154.19 \\
\hline $7 \mathrm{H}-1 \mathrm{~N}$ & 160.75 & 82.93 & 118.47 \\
\hline 0H-2N & 232.48 & 274.64 & 329.18 \\
\hline $3 \mathrm{H}-2 \mathrm{~N}$ & 232.48 & 284.01 & 175.51 \\
\hline $7 \mathrm{H}-2 \mathrm{~N}$ & 232.48 & 198.41 & 188.19 \\
\hline
\end{tabular}

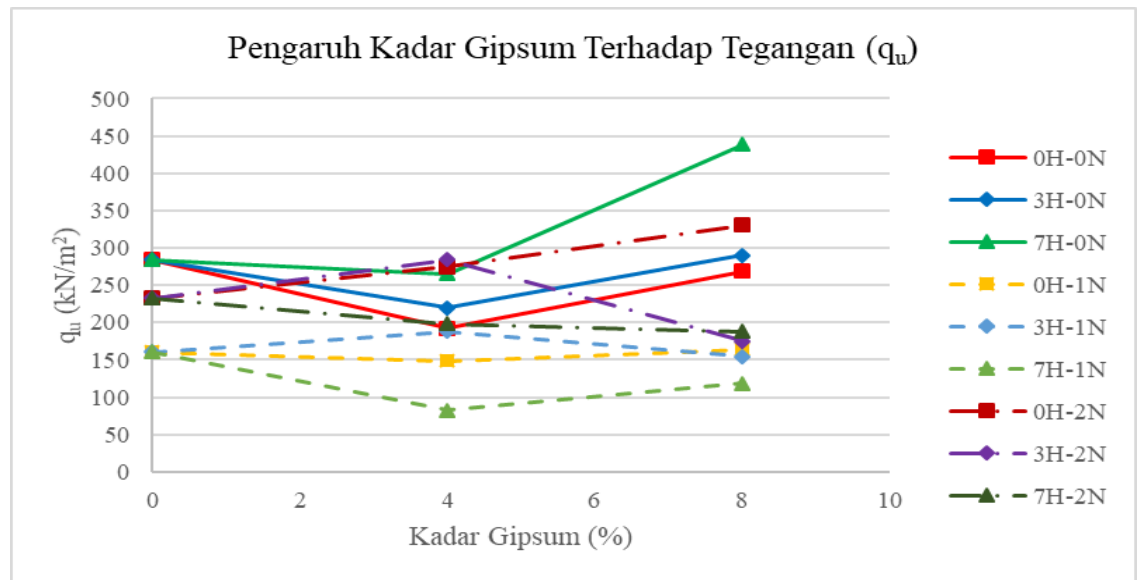

Gambar 6 Grafik Nilai qu Terhadap Kadar Gipsum

\section{Pengaruh Jumlah Siklus Terhadap Tegangan Pada Tiap Kondisi Kadar Gipsum dan Pemeraman}

Rangkuman rata-rata nilai $\mathrm{q}_{\mathrm{u}}$ dari 2 sampel pada setiap kondisi dapat dilihat pada Tabel 8 dan grafik nilai $\mathrm{q}_{\mathrm{u}}$ terhadap jumlah siklus dapat dilihat pada Gambar 7.

Tabel 8. Rangkuman Rata-rata Nilai $\mathrm{q}_{\mathrm{u}}$ untuk Analisis Jumlah Siklus

\begin{tabular}{|c|c|c|c|}
\hline \multirow{2}{*}{ Kondisi } & \multicolumn{3}{|c|}{$\mathrm{q}_{\mathrm{u}}\left(\mathrm{kN} / \mathrm{m}^{2}\right)$ untuk Jumlah Siklus $(\mathrm{N})$} \\
\cline { 2 - 4 } & 0 & 1 & 2 \\
\hline $0 \%-0 \mathrm{H}$ & 284.27 & 160.75 & 232.48 \\
\hline $4 \%-0 \mathrm{H}$ & 192.19 & 148.85 & 274.64 \\
\hline $4 \%-3 \mathrm{H}$ & 219.35 & 188.19 & 284.01 \\
\hline $4 \%-7 \mathrm{H}$ & 265.32 & 82.93 & 198.41 \\
\hline $8 \%-0 \mathrm{H}$ & 268.88 & 163.90 & 329.18 \\
\hline $8 \%-3 \mathrm{H}$ & 290.13 & 154.19 & 175.51 \\
\hline $8 \%-7 \mathrm{H}$ & 438.17 & 118.47 & 188.19 \\
\hline
\end{tabular}




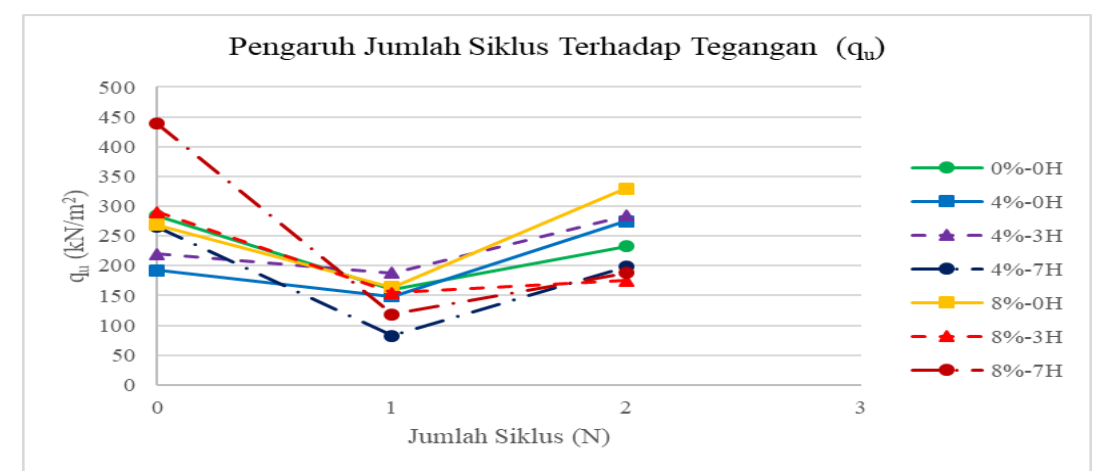

Gambar 7. Grafik Nilai qu Terhadap Jumlah Siklus

\section{Pengaruh Waktu Pemeraman Terhadap Tegangan Pada Tiap Kondisi Kadar Gipsum dan Jumlah Siklus}

Rangkuman rata-rata nilai $\mathrm{q}_{\mathrm{u}}$ dari 2 sampel pada setiap kondisi dapat dilihat pada Tabel 9 dan grafik nilai $\mathrm{q}_{\mathrm{u}}$ terhadap waktu pemeraman dapat dilihat pada Gambar 8

Tabel 9 Rangkuman Rata-rata Nilai $\mathrm{q}_{\mathrm{u}}$ untuk Analisis Lama Pemeraman

\begin{tabular}{|c|c|c|c|}
\hline \multirow{2}{*}{ Kondisi } & \multicolumn{3}{|c|}{$\mathrm{q}_{\mathrm{u}}\left(\mathrm{kN} / \mathrm{m}^{2}\right)$ untuk Lama Pemeraman (Hari) } \\
\cline { 2 - 4 } & 0 & 3 & 7 \\
\hline $4 \%-0 \mathrm{~N}$ & 192.19 & 219.35 & 265.32 \\
\hline $4 \%-1 \mathrm{~N}$ & 148.85 & 188.19 & 82.93 \\
\hline $4 \%-2 \mathrm{~N}$ & 274.64 & 284.01 & 198.41 \\
\hline $8 \%-0 \mathrm{~N}$ & 268.88 & 290.13 & 438.17 \\
\hline $8 \%-1 \mathrm{~N}$ & 163.90 & 154.19 & 118.47 \\
\hline $8 \%-2 \mathrm{~N}$ & 329.18 & 175.51 & 188.19 \\
\hline
\end{tabular}

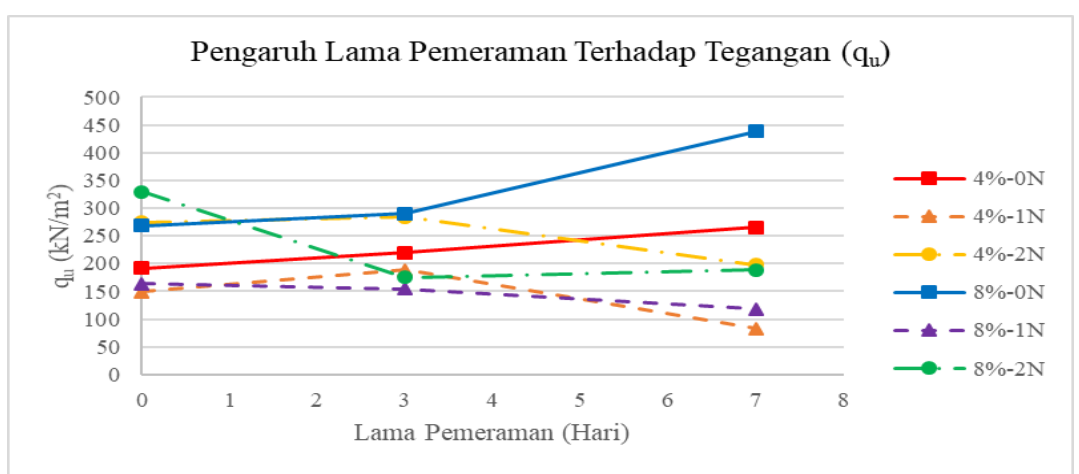

Gambar 8 Grafik Nilai qu Terhadap Lama Pemeraman

\section{KESIMPULAN}

1. Sampel tanah yang diambil pada lokasi Jababeka, Cikarang, merupakan tanah lanau dengan plastisitas tinggi / High Plasticity Silt (MH), dengan persentase Silt 56.79\% - 74.42\%, nilai Specific Gravity rata-rata 2.70, kadar air $40 \%-45 \%$, Saturasi $98.22 \%-98.71 \%$, angka pori $1.10-1.23$, dan porositas $0.52-0.55$ pada kondisi tanah asli.

2. Dari hasil uji Atterberg Limits diperoleh nilai Indeks Plastisitas atau Plasticity Index (PI) sebesar $45.47 \%$ 46.50\% dan dari uji Hydrometer diperoleh Colloid Content sebesar 22.60\% - 38.85\%, maka menurut Tabel 2.3 Relation of soil index properties to expansion potential of high-plasticity clay soils (USBR 1998:46), sampel tanah yang diambil memiliki Degree of Expansion very high.

3. Dari hasil uji X-Ray Diffraction diperoleh kadar Montmorillonite sebesar $11 \%$, sehingga sampel tanah yang diambil berpotensi ekspansif. Sampel tanah yang diuji juga termasuk tanah aktif karena nilai aktivitasnya (Ac) adalah $2.22>1.25$.

4. Pengujian hubungan Plasticity Index (PI) dengan Temperatur Suhu Tinjauan diperoleh hasil bahwa semakin tinggi suhu pengeringan tanah, maka nilai Plasticity Index sampel akan semakin menurun, sehingga untuk metode pengeringan pada siklus basah-kering digunakan pengeringan udara. 
5. Dari hasil uji pemadatan Standard Proctor diperoleh hasil kadar air optimum sampel yang diuji adalah $30.60 \%$ dan kepadatan keringnya $\left(\gamma_{\text {dry }}\right)$ adalah $13.43 \mathrm{kN} / \mathrm{m}^{3}$

6. Nilai kuat tekan bebas tertinggi diperoleh pada kondisi sampel dengan penambahan gipsum $8 \%$ dengan waktu pemeraman 7 hari dan tanpa siklus, yaitu sebesar $438.17 \mathrm{kN} / \mathrm{m}^{2}$. Nilai kuat tekan bebas ini meningkat $54.14 \%$ dari sampel tanah yang tidak dicampur gipsum yang nilai kuat tekan bebasnya sebesar $284.27 \mathrm{kN} / \mathrm{m}^{2}$.

7. Nilai kuat geser $\left(S_{u}\right)$ yang didapat meningkat $54.14 \%$ karena rumus kuat geser adalah setengah dari kuat tekan bebas $\left(\mathrm{q}_{\mathrm{u}}\right)$. Pada penelitian sebelumnya yang menggunakan metode direct shear, peningkatan kuat geser yang didapat adalah $116.34 \%$ untuk penambahan gipsum $8 \%$ dengan waktu pemeraman 14 hari.

8. Dari pengamatan penambahan kadar gipsum terhadap kuat tekan bebas sampel, diperoleh hasil bahwa nilai kuat tekan bebas sampel yang tidak melalui siklus dapat meningkat pada penambahan gipsum sebesar $8 \%$ dengan waktu pemeraman 3 hari dan 7 hari. Namun untuk sampel yang tidak diperam pada penambahan gipsum $4 \%$ dan $8 \%$ keduanya memiliki nilai kuat tekan bebas lebih rendah dibanding sampel tanpa penambahan gipsum. Untuk sampel dengan penambahan gipsum 4\%, nilai kuat tekan bebasnya selalu lebih rendah dibanding sampel tanpa penambahan gipsum.

9. Dari pengamatan jumlah siklus terhadap kuat tekan bebas sampe, diperoleh hasil bahwa setelah sampel mengalami siklus basah-kering sebanyak 1 kali, maka nilai kuat tekan bebas sampel menjadi turun. Namum untuk sampel yang melalui siklus basah-kering 2 kali, nilai kuat tekan bebas sampel cenderung naik.

10. Dari pengamatan lama pemeraman terhadap kuat tekan bebas sampel, diperoleh hasil bahwa untuk sampel yang tidak melalui siklus basah-kering, semakin lama waktu pemeraman yang dilakukan pada sampel yang ditambah gipsum, maka semakin besar nilai kuat tekan bebasnya. Namun setelah melalui siklus basah-kering, nilai kuat tekan bebas sampel cenderung turun dengan semakin lamanya waktu pemeraman.

11. Dari penelitian ini dapat disimpulkan bahwa gipsum tidak tepat digunakan untuk stabilisasi pada tanah ekspansif pada lokasi Jababeka, Cikarang.

\section{DAFTAR PUSTAKA}

ASTM D2166/D2166M-13. 2014. Standard Test Method for Unconfined Compressive Strength of Cohesive Soil. United States: American Society for Testing and Materials.

ASTM D2487-10. 2014. Standard Practice for Classification of Soils for Engineering Purposes (Unified Soil Classification System). United States: American Society for Testing and Materials.

ASTM D4318-10. 2014. Standard Test Methods for Liquid Limit, Plastic Limit, and Plasticity Index of Soils. United States: American Society for Testing and Materials.

Bowles, J. E. 1979. Physical and Geotechnical Properties of Soils. New York: McGraw-Hill.

Coduto, Donald P., Kitch, William A., dan Yeung, Man-Chu R. 2016. Foundation Design Principles and Practices. Third Edition. California: Pearson.

Das, Braja M. 1995. Mekanika Tanah (Prinsip-prinsip Rekayasa Geoteknis). Trans. Noor Endah Mochtar dan Indrasurya B. Mochtar. Jilid 1. Jakarta: Erlangga.

Hardiyati, Siti. Studi Potensi Mengembang dan Kekuatan Tanah Lempung Ekspansif Dengan dan Tanpa Kapur Akibat Siklus Berulang Basah-Kering. Tesis, Universitas Diponegoro, Semarang, 2003.

Ingles, O. G. dan J. B. Metcalf. 1972. Soil Stabilization Principles and Practice. Melbourne: Butterworths.

Makarim, Chaidir Anwar, Yudistira Yacobus Raynaldo, dan Alvin. 2017. Pengantar Geologi dan Mekanika Tanah. Jakarta: Chaidir Anwar Makarim.

Seed, H.B., Woodward, R.J. dan Lundgren, R.. Prediction of Swelling Potential for Compacted Clays. Journal ASCE. Soil Mechanics and Foundations Div.. Vol. 88. 1962

Skempton, A. W. (1953). The Colloidal Activity of Clays. Proceeding $3^{\text {rd }}$ International Conference on Soil Mechanics and Foundation Engineering. Volume 1 Number 57 - 61. London.

Smith, M. J. 1984. Mekanika Tanah. Trans. Elly Madyayanti. Edisi Keempat. Jakarta: Erlangga.

USBR. 1998. Earth Manual Part 1. Third Edition. Colorado: U.S. Bureau of Reclamation.

Wesley, Laurence D. 2012. Mekanika Tanah untuk Tanah Endapan dan Residu. Trans. Laurence D. Wesley dan Satyawan Pranyoto. Yogyakarta: ANDI.

Wibawa, Arif. 2015. Pengaruh Penambahan Limbah Gypsum Terhadap Nilai Kuat Geser Tanah Lempung. Jurnal Fropil. Universitas Bangkal Belitung, Bangka Belitung. 